243 STEEN NEPPER LARSEN

Lektor

Danmarks institut for Pædagogik og Uddannelse (DPU),

Campus Emdrup, Aarhus Universitet

\title{
ANTIKAPITALISTISK, \\ SAMTIDSKRITISK OG USAMTIDIG KUNSTHISTORIESKRIVNING
}

Mikkel Bolt

\section{SAMTIDSKUNSTENS}

METAMORFOSE

248 sider. Antipyrine, Aarhus, 2016

I et markant anslag blot tre-fem linjer inde i sin bog Samtidskunstens metamorfose pointerer kunsthistoriker og lektor på Institut for Kunst- og Kulturvidenskab på Københavns Universitet Mikkel Bolt: "Bogen er ikke en systematisk fremstilling, og den er ikke kendetegnet ved en sammenhængende og entydig stemme". Eksplicitte negationer af den slags - for ikke at sige dobbeltnegationer - er altid værd at bide mærke i og ikke mindst skeer med.
For efter endt læsning af Bolts seks kapitler: "Grænser for deltagelse", "Avantgardens efterord", "Den lange march gennem institutionerne", "Den socialt engagerede kunstkritik", "Reklamearkitektur og logistik" og "At forestille sig fremtiden" tegner der sig en eksplicit kapitalismekritisk stemme, der serverer læseren for en ubændig og revolutionært utålmodig fortælling om samtidskunstens hårde odds og mange nederlag i en forrykt, uretfærdig og ulige verden præget af Kommerz, fordummelse og tilpasning. Fortabte drømme om en radikal anderledeshed for både samfund, liv og æstetiske udtryksformer passerer revy for og får 
244 KULTUR \& KLASSE * $125 * 2018$

deres besyv med af den marxistisk skolede forfatter.

Stemmen er med andre ord éntydig og stilen ikke just slingrende. Det er næppe for meget sagt, at stemmen er både særegen og $\mathrm{i}$ bedste forstand - ihukommende filosoffen Ernst Blochs slidstærke begreb - såvel usamtidig som usamtidighedsindfangende, dvs. på én gang gammelklog, historisk velinformeret, ung og altid på bedste paradoksale vis både uanfægtet og vildt anfægtet.

Distinktionen mellem en akademisk analyse af kunstinstitutionerne og kunstværkerne, den normative analyse af kapitalismens globale og politiske økonomi og (u)mulighed af politisk handling går - og skal ifølge penneførerens intention og bogkomposition gå - i opløsning i de seks kapitler, hvoraf de fem tidligere har set dagens lys som tidsskriftsartikler $i$ ind-og udland og/eller været præsenteret som foredrag på konferencer mellem 2012 og 2015.

Det er Bolts credo, at den marxistiske kunsthistorie, han hylder og bedriver, ikke kan nøjes med at beskrive kunstværkerne eller at konstatere, at de findes. Snarere læser og skriver han (om) samtidskunsten "som en repræ- sentation af samtiden som historie...".

\section{FOR FÅ VÆRKANALYSER}

Desværre synes prisen for denne tilgang at blive, at der efter mit temperament og min smag for det konkrete byder sig for få dybdeborende analyser af singulære kunstværker til i bogen. Der dvæles som oftest ikke ved kunstværkernes aura, originalitet, gehalt og indre formsprog, omend det velskrevne og informative kapitel "Avantgardens efterskrift" og ligeledes kapitlet "At forestille sig fremtiden" bestemt har blik for at tænke højt med enkelte situationistiske, dadaistiske og surrealistiske institutions- og normalitetsbetvivlende (anti)værker.

Således udformede situationisten Michèle Bernsteins i 1963 en billedserie med den originale, provokerende og historisk-kontrafaktiske titel: "Victoires du prolétariat" (Proletariatets sejre). Hendes forestillinger om "en anden fortid og dermed en anden nutid og fremtid" følger Bolt til dørs, og det giver hans bog kvalitet, at denne kunstudstillings spor forfølges videre til en kælder i et kollektiv i Odense (Huset) - hvorefter han blotlægger de 
rige tankemæssige og kunstneriske snoninger, der bredte sig fra Jørgen Nash og Drakabygget i Sverige og ikke mindst fra Guy Debords øjenåbnende og skånseløse kritik af skuespilssamfundet, der blev formuleret i Frankrig, men snart bredte sig til alverdens kunstkendere, kunstkritikere o g kapitalismekritiske kunsthistoriestuderende. Marx' vareanalyse og værdiformskritik blev suppleret af en oplysende og velgørende kritik af billed-varen i samtidens accelererende, semiotiske, politiske og æsteticere(n)de tegn- og pengetrafik.

Snarere end at byde på grundige værkanalyser er det bogens styrke, at den - ud over at præsentere en meget fin og højaktuel tydning af Rudi Dutschkes stedsegrønne 1967-formulering af "Den lange vej gennem institutionerne" (= overskriften på kapitel 3), som de revolutionære tvunget af omstændighederne må begive sig ud på, mens de venter tålmodigt på, at "mennesker bliver anderledes" - foretager en række meget grundige 'samtaler' med nogle bugnende håndfulde af verdens vigtigste kunstteoretikere og kunstinteresserede samfundskritikere, såsom Peter Bürger, Fredric Jameson, Peter Osborne, Boris Groys, Hal
Foster, Grant Kester, Claire Bishop, David Joselit, Andrea Fraser, Giovanni Arrighi, T.J. Clark, Henry Jenkins, Nicolas Bourriaud, Gerald Raunig, Brian Holmes, Bruno Latour, Alain Badiou, Chantal Mouffe, Giorgio Agamben, Jacques Rancière og Comité invisible (Den usynlige komité) ${ }^{1}$. Bolt spørger kritisk til og afprøver ofte deres begreber. Det kommer der til tider både original tænkning og nye perspektiver ud af.

\section{MEGET STORE ORD}

Bolt er ikke bange for de store proklamationer: "Tekster der ikke er et udtryk for og accelererer det kaos vi lever i, duer ikke", "... den marxistiske kulturkritiks opgave er så at udvikle en kulturel analyse, der kan afbilde den globale senkapitalismes komplekse og ulige 'geografi", "Tiden er ikke til reformisme, ikke til mindre vold, men til mere", "Institutionerne skal smadres som et led i ødelæggelsen af kapitalismen. Det var planen,

1 Det havde så absolut klædt bogen at have været udstyret med et forfatter- og emneregister og såmænd også med én samlet litteraturliste i rosinens pølseende. 
246 KULTUR \& KLASSE * $125 * 2018$ ANMELDELSER

og det er planen", og "kunsten er revolutionær (eller den er ikke)" (som Bolt slår fast med reference til den altid i teksten og tanken nærværende Guy Debord). Og efter at have skildret "en veritabel revolutionsbølge i Nordafrika og Mellemøsten", der tog sin begyndelse i 2011, og efter at have taget et par optimismeafstivende afstikkere til både Occupy-bevægelserne i Vesten og til strejkebevægelserne i Østen konkluderer han: "Overalt afvises en tingsliggjort verden". Verden står med andre ord på nippet til "en egentlig proletarisk revolution".

Det er næsten alt for let at skyde disse bastante formuleringer og håbefulde overdrivelser ned. Afspejlingsmarxismen er ikke bare blevet udstillet til spot og spe via dekonstruktionsorienterede og poststrukturalistiske læsninger de sidste 30-40 år. De bedre af 1960'ernes og 1970'ernes rekonstruktionsmarxister og kritiske teoretikere og æstetikteoretiske tydninger i Theodor W. Adornos kølvand har også gentagne gange advaret stålsatte (kapitalisme)kritikere imod fristelsen til at reducere kunsten(s udtryk) til økonomi eller politik. Såkaldt ikke-revolutionær kunst har eksempelvis også en ret til at eksistere, til at blive til og til at blive taget alvorligt (også af den politiske kunstteoretiker).

At kunstværket med Adornos ord fra Ästhetische Theorie (udg. posthumt i 1970) har samfundet i sig, gør ikke kunsten til enten en afbildning af samfundet endsige til dets let afkodelige antitese. Omgangen med kunstværkets autonomi og forsvaret for dets principielle ikke-identitet fordrer og inviterer principielt til en dvælen ved dets materialitet, formsprog, koncept og udtryk. Kunstværket er aldrig blot en sekundær overbygning på en primær basis, en overflade for en dybere sandhed eller en fremtrædelsesform for et væsen.

Bolts svært indløselige - men efter min mening samtidig også højrelevante - problemformulering, præsenteret i slutningen af bogen, tager sig således ud: "Hvordan artikulerer vi en altomfattende kritik af det kapitalistiske samfund uden at formulere en vision om en bedre fremtid og uden planer for en anden styring af den kapitalistiske økonomi (som socialdemokrater og leninister forgæves har forsøgt det.)"?

Dette ambitiøse og nærmest udvejs- og hjemløse spørgsmål sætter Bolt ind i en filosofisk, politisk og kunsthistoriske kontekst 
ved at skrive: "Det var netop den opgave, revolutionære som Naville, Bataille, Benjamin og senere Benjamin og Debord satte sig for at løse: en total forvandling af hverdagslivet (samfund og mennesker). Det var den revolutionære marxismes mission, det var projektet". Og han fortsætter med at slå fast, at det ikke bare var projektet; men at det er projektet for en venstrefløj, der må have viljen og modet til at opskalere sine politiske ambitioner "med henblik på skabelsen af en anden fremtid".

\section{VAR OG ER}

Med den gentagne anvendelse af den enkle dualt-verbalretoriske glidning mellem de to tider af infinitivformen 'at være': "var" og "er" ind(for)skriver Bolt sig som en nutidig arvtager af og stemme blandt de fortidsuforløste kræfters selskab. Som han selv fremhæver, er han, selvom han på mange måder har skrevet en sørgmodig nekrolog over avantgarden i det 20. århundrede, "overbevist om, at avantgarden forbliver en af de bedste indgange til spørgsmålet om kunstens kritiske potentiale i et kapitalistisk samfund./.../Med andre ord: uden avantgarde ingen radikal kritik. Det er udgangspunktet".

Bolt tyder avantgarden som et broget kor af systemkritiske vovehalse, der jagtede og til tider skabte en mening hinsides merværdien, markedet og det lette 'meneri'. Avantgarden må løftes op af "historiens affaldskurv", ikke mindst han - kongenialt med den engelske, marxistiske kunsthistoriker John Roberts' formuleringer fra "holder det revolutionære perspektiv i live i en post-revolutionær tid", og fordi den avantgardistiske kunsts kritik af den instrumentelle fornuft ufortrødent træder frem som "en pladsholder for et kommende samfund".

I kapitlet "Reklamearkitektur og logistik" giver Bolt en ætsende veloplagt kritik af bilfabrikken BMW's produktionsanlæg i Leipzig, der i 2013 blev kåret til den bedste fabrik i Europa af en lang række magtfulde institutioner og enkeltpersoner. Det dynamiske, fleksible og hyper-rene anlæg, hvor der afhængigt af efterspørgslens dataindhøstede fluktuationer arbejdes mellem 70 og 140 timer om ugen, er tegnet af Zaha Hadid Architects. Avantgardistarkitekten træder på denne måde i kapitalakkumulationens tjeneste, mens 
248 KULTUR \& KLASSE * $125 * 2018$

avantgardetermen synes at miste enhver betydning, skriver Bolt. Videre går hans analyse til en gennemgang af containertrafikkens skelsættende betydning for den moderne kapitalismes rigdomsform, der med sociologen Thomas Reifers ord, der parafraserer Karl Marx' berømte første sætning i Das Kapital fra 1867, umiddelbart og ca. 150 år senere tager sig ud som "en uendelig akkumulation af containere". Bolt kalder meget velvalgt just-in-time-logistikken, der styrer de globale varebevægelser og oceanerne, på skinnerne og på vejene, for "kapitalen på speed".

Men kapitlet ender igen med nogle meget store og svært gennemskuelige formuleringer af typen: "Kapitalen er i færd med at æde sig selv og destinerer milliarder til elendighed og død...", og "Vi kan ikke negere negationen (gennem en anden brug), men kun ødelægge den". Bolt har naturligvis ret $i$, at kapitalens ulige udvikling, der på den ene side træder frem som den klinisk-perfekte og højeffektive BMW-fabrik i Leipzig, på den anden side dømmer millioner af mennesker til ikke at være værd at udpresse merværdi af, endsige at ansætte; men det ændrer ikke ved, at mange af verdens fattige menne- sker og aldeles udsatte og lykkeridende migranter hellere end gerne ville lade sig udbytte af BMW end at læse Bolts eller for den sags skyld Marx' eller mine bøger for slet ikke at tale om at fantasere om at gribe til politisk-revolutionær handling across and all around the Globe.

Dertil kommer, at den fundamentale negation af teknologien og produktivkræfterne - bogstaveligt talt en fysisk ødelæggelse af ikke bare disse, men også en smadring af institutionerne - kommer til at efterlade de revolutionære (analytikere) med lidt af et oprydningsarbejde og en sindssygt omfattende nybyggervirksomhed. Alt fra skoler til universiteter, fra hospitaler til juridiske institutioner, fra kommunikations- til trafiksystemer skal således først totalsmadres for derefter i endnu ukendte materielle og sociale former at blive realiseret på radikalt nye måder. Man må da blot håbe, at Bolt har mere end én Fugl Fønix til at hjælpe sig.

\section{RELATIONEL ÆSTETIK SOM KUNSTENS} PSEUDODEMOKRATISERING Skarpsindig er Bolts analyse i kapitlet "Grænser for deltagelse". Han viser, at beskueren og del- 
tageren blev aktiveret i kunstens haller i den forkælede del af verdens metropoler samtidig med, at "forestillingen om gennemgribende sociale forandringer" ebbede ud i begyndelsen af 2000-årene, og at denne opgradering og besyngelse af deltagelsesformerne skete stort set samtidig med, at verden blev hjemsøgt af en hidtil uhørt kreativitetshype blandet op med en anmassende neoliberal oplevelsesøkonomi, der søgte at kommercialisere meget af det, der fundamentalt ikke lader sig vareliggøre, bl.a. menneskers oplevelser, drømme, idéer og tanker (se fx mine opslag om 'oplevelsesøkonomi', 'eksternaliteter', 'immaterialitet' og 'kognitiv kapitalisme' i sNL og Inge Kryger Pedersen (Red.): Sociologisk leksikon, 2013 [2011].

Han viser også, at pseudoinvolveringen altid er underkastet bestemte regler og forventninger, og at politiet altid er klar i kulissen, når kunsten indforskrives i en top-down-politik. Således blev en flok graffiti-kunstnere, der indtog Oscar Niemeyer Pavillonen på São Paulo Biennalen i 2008, anklaget for "kriminel vandalisme" af kuratorerne og Biennale-administrationen, selvom biennalen ellers ganske quasi-progressivt var blevet italesat som et "sted for muligheder" og som "et sted der skal frigøres", som det hed i kuratorerne Ivo Mesquitas og Ana Paula Cohens "Introduction" til den 28. kunstbiennale i den store by.

For at bære ved til en "Socialt engageret kunstkritik", som bogens fjerde kapitel er blevet kaldt, skal der mere til. Den relationelle æstetik (Nicolas Bourriaud m.fl.) og deltagelseskunsten må efter Bolts mening og hans hjemmelsmænd, de amerikanske kunsthistorikere og -teoretikere Grant Kester og Brian Holmes, afløses af en socialt engageret kunst, der udvider kunstens kulturelle praksis igennem en række institutionskritiske afsøgninger af nye muligheder.

Men ak, efter en del rundgange ender Bolt med at slå fast, at Kester m.fl. ikke har meget at byde på: "Der er bare en verden, som den socialt engagerede kunstner forbedrer og reparerer, og som den socialt engagerede kritiker empatisk beretter hjem om". Kort sagt forbliver Kester "afhængig af en lidet dialektisk forståelse af forholdet mellem kunst, revolution og kapitalisme". Huggene falder prompte og uden omsvøb. 
STEDFORTRÆDERPOLITIK OG TRANSFORMATION AF HISTORISKE NEDERLAG TIL FREMTIDENS SEJRE I en tæt diskussion med John Roberts lægger Bolt ikke skjul på, at det bestemt ikke er problemløst at indtage en position, hvori og hvorfra man kan føle sig placeret foran (i rollen som mere avanceret, klogere og vidende end) andre mennesker: "Avantgarden er kendetegnet ved en kompleks og ofte modsætningsfyldt udsigelsesposition, hvor forholdet til massen aldrig er ligetil, men derimod karakteriseret af lige dele foragt og begær".

På den anden side finder jeg det overbevisende med den tyske filosof Peter Sloterdjks ord fra Die Verachtung der Massen (2000, da. Masse og foragt, 2002), at det er nødvendigt, hvis man ikke skal tabe sin værdighed, sin evne til at undre sig og sit håb, ikke bare at bekæmpe massen i sig selv, men også i decentreringskunstens navn at stå på mål for og eller at afsøge en række vertikaler, der kan bekæmpe horisontalplørenivelleringerne. Sloterdijk taler ligefrem og ganske vederkvægende om beundringsøvelser, og i anden sammenhæng har jeg betegnet hans unikke og multi-sfær- ologiske kropsfænomenologi som en øvelsesantropologi (se fx SNL: "Menneskets livslange anden fødsel. Om Peter Sloterdijks sfærologi og filosofiske antropologi", Vagant 1, Bergen 2009).

Om dette dilemma gør avantgarden (den fortidige, nutidige og fremtidige) til et notorisk håbløst og altmodisch stedfortræderpolitisk projekt, der altid-allerede vil mislykkes eller tværtimod gør avantgarden - og ikke mindst dens kunstneriske udtryk(sformer), der må være andet og mere end politisk aktivitet fortsat med andre midler - uomgængelig for at tænke forandring, må selvfølgelig komme an på grundige drøftelser og ikke mindst kunstneriske eksperimenter og hidtil usete teoretisk-begrebslige ydelser. Dertil kommer, at 'avantgarden' aldrig findes i bestemt form éntal, men kun som en paraplyterm for en række virkeformer i ubestemt form flertal.

Bolt er da også inde på, at avantgarden ikke kan virkeliggøre kunsten - endsige et helt andet samfundsliv, som det faktisk var ambitionen - uden for institutionen, og det er ikke bare, fordi den er decimeret og svær at få øje på; men fordi der endnu ikke er opstået nogen nye former (fx kunst- 
former, partier eller bevægelser), samtidig med at det erfares af både kritiske kunstnere, kritiske teoretikere og politiske aktivister, at de gamle ikke længere duer.

\section{EXIT}

Føromtalte Michèle Bernstein bragte fortiden i fertil cirkulation ved at genopføre Pariserkommunens og den korte sommers anarkistiske spanske republiks historiske nederlag som sejre "ved hjælp af varekapitalismens egne produkter". Værkerne blev 'opført' ved hjælp af påklistrede legetøjssoldater, plastiktanks og påklaskede ansamlinger af maling... alt sammen formidlet på en børnehaveæstetisk facon, skriver Bolt for derefter at fortsætte og konkludere: "Vi har nøjagtig de samme aktører, men nu helt anderedes. Pointen er selvfølgelig, at alt er muligt, selv den spektakulære økonomis rædsler, men også en anden verden".

På falderebet af det, der efterhånden er blevet til en forvokset anmeldelse, vil jeg hævde, at denne påstand er dobbelt usikker. For det første er der ikke mange kommunarder anno 2018, der er rede til at sætte liv og lemmer på spil for at realisere anarkismens radikale frihedsdrømme. Såvel realiseringsbetingelserne som det antikapitalistiske fodfolk af ikke-plastik savnes. For det andet har kapitalismen vist sig at have mere end ni liv, som forfatteren til Samtidskunstens metamorfose vil vide og være den første til at fortælle sine eksklusive læsere igen og igen. 